\title{
Dialogic educational practices in the context of child intoxication: an approach based on Paulo Freire
}

\author{
Práticas educativas dialógicas no contexto das intoxicações infantis: uma abordagem freireana
}

Prácticas educativas dialógicas en el contexto de las intoxicaciones infantiles: un abordaje basado en Paulo Freire

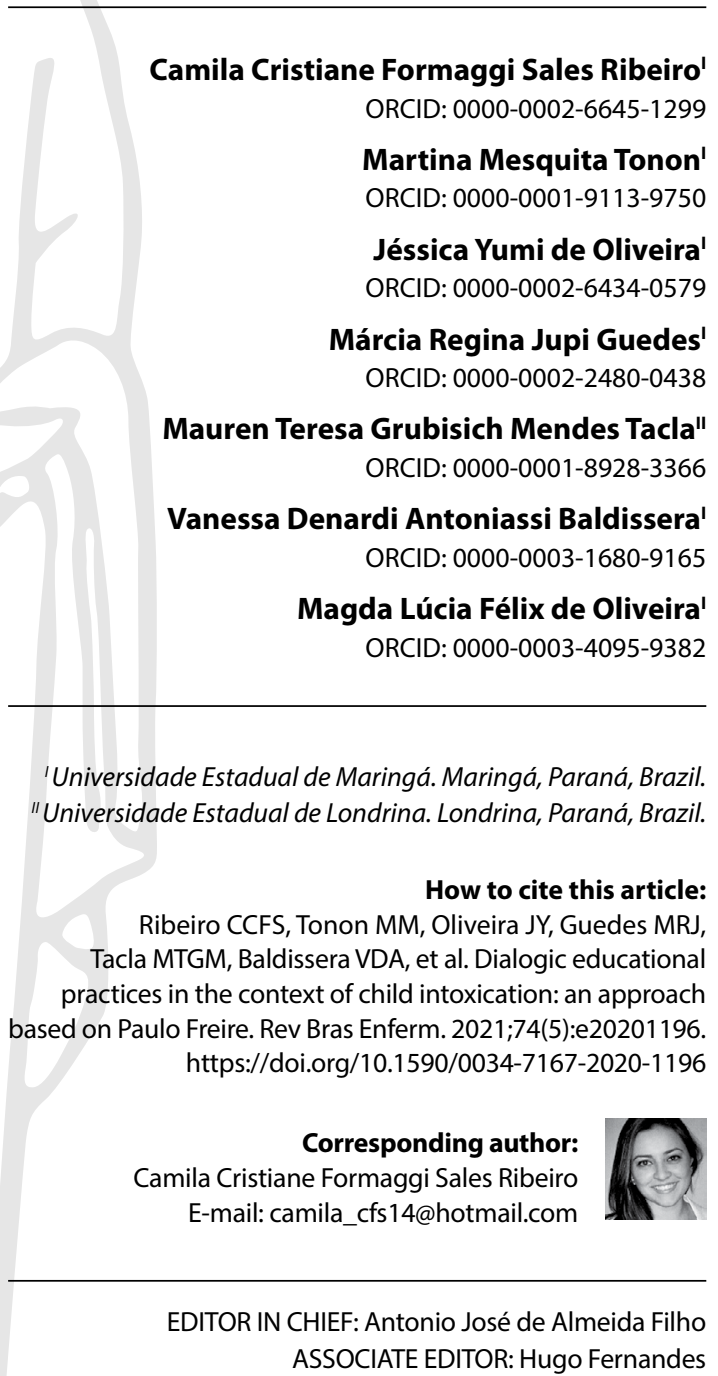

Submission: $11-26-2020$

Approval: 03-05-2021

\section{ABSTRACT}

Objective: To analyze the knowledge and practices of education of Family Health Strategy professionals regarding child intoxication for the autonomy and empowering of the families. Methods: Qualitative research, carried out through semistructured interviews with 50 professionals from the Family Health Strategy of a city in the Northwest of Paraná. Data was problematized using Paulo Freire's sociocultural approach and its concepts of dialogism and autonomy. Results: The statements showed the many ways in which the care for child intoxication is perceived and their relations with educational action, but these were traditional educational practices, with elements focused on the dissemination of information about health-disease, probably because the dialogic approach is still abstract and has no interface with the concrete practices. Final considerations: The education knowledge and practices of the professionals for the autonomy and empowering of families suggested that there is a transition stage between the biomedical model, focused on a cure, and the dialogical one. Descriptors: Health Education; Primary Health Care; Poisoning; Child Health; Freirean Approach.

\section{RESUMO}

Objetivo: Analisar os saberes e práticas educativas dos profissionais da Estratégia Saúde da Família em intoxicação infantil para autonomia e empoderamento das famílias. Métodos: Pesquisa qualitativa, realizada por meio de entrevistas semiestruturadas com 50 profissionais das equipes da Estratégia Saúde da Família de um município do noroeste do Paraná. Os dados foram problematizados por meio da concepção dialógica e da autonomia da abordagem sociocultural de Paulo Freire. Resultados: Os depoimentos revelaram várias formas de perceber o cuidado em intoxicação infantil e sua relação com a ação educativa, mas estas eram práticas educativas tradicionais, com elementos centrados em difundir informações sobre saúde-doença, provavelmente porque a abordagem dialógica ainda é abstrata e sem mediação com a prática concreta. Considerações finais: Os saberes e as práticas educativas dos profissionais para autonomia e empoderamento das famílias sugeriram uma fase de transição entre o modelo curativista/biomédico e o dialógico.

Descritores: Educação em Saúde; Atenção Primária à Saúde; Envenenamento; Saúde da Criança; Abordagem Freireana.

\section{RESUMEN}

Objetivo: Analizar los saberes y prácticas educativas de profesionales de la Estrategia Salud de la Familia en intoxicación infantil para autonomía y empoderamiento de familias. Métodos: Investigación cualitativa, realizada por medio de entrevistas semiestructuradas con 50 profesionales de equipos de la Estrategia Salud de la Familia de un municipio del noroeste de Paraná. Datos fueron problematizados por medio de la concepción dialógica y de la autonomía del abordaje sociocultural de Paulo Freire. Resultados: Deposiciones revelaron varias maneras de percibir el cuidado en intoxicación infantil y su relación con la acción educativa, pero estas eran prácticas educativas tradicionales, con elementos centrados en difundir informaciones sobre salud-enfermedad probablemente porque el abordaje dialógico aún es abstracto y sin mediación con la práctica concreta. Consideraciones finales: Los saberes y las prácticas educativas de los profesionales para autonomía y empoderamiento de las familias sugirieron una fase de transición entre el modelo curativa/biomédico y el dialógico. Descriptores: Educación en Salud; Atención Primaria de Salud; Envenenamiento; Salud del Niño; Enfoque Freireano. 


\section{INTRODUCTION}

Intoxication is an important public health problem and a significant cause of morbidity and mortality in children, representing approximately $3 \%$ of all patients hospitalized in emergency services $^{(1)}$. Every year, nearly 45 thousand children and adolescents below 20 years old die due to intoxication, and it has been reported that, among people in this age group, the rate of death due to poisoning is of 1.8 per 100 thousand throughout the world $d^{(1-2)}$.

To Disfani et al. ${ }^{(2)}$, the rates of incidence and mortality due to child intoxication can be diminished by implementing educational intervention programs, since intoxications are avoidable events that can be prevented and are conditions that can be impacted by actions from the Primary Health Care (PHC). As a result, home, the family environment, is a privileged setting for the development of actions that promote health. The home can be especially unsafe for children, since it contains objects and materials that offer risk in all of its rooms. This is especially true with regard to the diversity of chemical products, which favor intoxication and are mostly stored in places that the child can easily access ${ }^{(3-4)}$.

Understanding the home environment of the family requires the mobilization of the health professionals, especially those from the Family Health Strategy (ESF), since the intoxication can manifest differently depending on the many environments where it takes place. Therefore, the proposals for integral attention to children and family's health should intervene through educational practices that include listening, the satisfaction of needs, and allow for autonomy, extrapolating simple assistance and connecting these people in social networks based on perspectives that lead to the confrontation and minimization of vulnerability factors $\mathrm{s}^{(5-6)}$.

However, the review of literature carried out for this study showed the scarcity of research that analyze the way in which care should be offered by the PHC in order to prevent child intoxication, from a dialogic perspective that aims to develop critical awareness, based on the understanding that the community is a place for social and cultural changes, as opposed to a place where to simply carry out investigations. Authors ${ }^{(5,7-8)}$ have highlighted that educational actions based on dialogic, pedagogical, and liberating referents are capable of promoting the autonomy of families and encourage them to assume the main role in the performance of collective action and in the exercise of citizenship.

The dialogic perspective proposed by Paulo Freire ${ }^{(9)}$ in his sociocultural approach is important as a reference on which to base the autonomy and empower families. This perspective is conducted by reflection-action, aiming to reach liberty not only in the cognitive field, but, essentially, in the social and political ones. In the scope of health, the epistemological constructs of Paulo Freire have pushed forward ${ }^{(5,10-11)}$ researches that propose to offer health education for the groups in the community, which is seen as a fruitful path to make viable new actors in a production of care that is committed to autonomy and to a critical awareness about reality.

As the perspective of the ESF workers is broadened with regard to their professional activities, it can be noted that an authentic dialog makes the professional-family relations easier, helping subjects to feel valued and aware of how important their social role is in the transformation of reality. This study is relevant because it aims to encourage ESF workers to reflect on dialogic educational practices based on effective communicational processes, to encourage autonomy, joint responsibility, and the valuing of families, in addition to aiding them to make decisions and change behaviors that could put their health at risk ${ }^{(8,12)}$.

Therefore, considering child accidents, especially intoxications, as preventable health issues that can be prevented and impacted by PHC actions, and considering the references of this work, that is, the educational practices in the perspective of Paulo Freire's dialogism, this study contributes for the knowledge in the field of child and family health, improving the actions of health workers as mediators of educational actions, attuned to the idea that the role of the family is strategic and central for policies that promote health and empowering.

\section{OBJECTIVE}

To analyze the educational knowledge and practices of Family Health Strategy professionals about child intoxication for the autonomy and empowering of the families.

\section{METHODS}

\section{Ethical aspects}

This research was approved by the Permanent Research Ethics Committee for Researches Involving Human Beings from the Universidade Estadual de Maringá. The study was approved by the Municipal Secretariat of Health from Maringá, and participants gave their spontaneous consent to participate in the study by signing the Free and Informed Consent Form.

\section{Type of study}

This study was designed following a qualitative, descriptive, and exploratory approach ${ }^{(13)}$. It results from a report that originated from the Master's Degree dissertation Práticas educativas no cuidado à intoxicação infantil na atenção básica: uma perspectiva dialógica (Educational Practices in the Care for Child Intoxication in Primary Care: a Dialogic Perspective), and followed all Consolidated Criteria for Reporting Qualitative Research (COREQ) ${ }^{(14)}$, which guide the writing of qualitative research articles.

\section{Study setting}

This study was carried out in the PHC network of the city of Maringá, located in the Northwest of the State of Paraná, in Brazil. This includes 35 Primary Health Care Units (UBS), associated to 9 Centers for Support to Family Health (NASF) and 74 ESF teams (ESFt). To determine the places where to carry out the study, the $\mathrm{PHC}$ units were separated according to the NASFs to which they were associated. One PHC Unit was selected in the scope of each NASF, adding up to 9 ESFts.

\section{Participants of the study}

The study counted on the participation of 50 professionals who worked in the 9 ESFts: 9 nurses, 7 nursing auxiliaries, and 34 community health agents (CHAs). The participants were chosen intentionally, 
since they were the main responsible for health education processes in the ESFts ${ }^{(15)}$. The study included those who had been working in the ESF for more than 12 months, regardless of their time working in the particular ESFt where they worked at the moment of the interview. Professionals who were on leave at the time of data collection were excluded - be it due to vacations, health leave, maternity leave, especial leave, or any other type of legal leave.

\section{Collection and organization of data}

The semistructured narrative interviews were chosen as the strategy to obtain data ${ }^{(16)}$, and aimed to understand dialogic educational practices in the context of child intoxication. The ESFts professionals were invited in person, by the main researcher, to participate in this study. The interviews were scheduled according to the time and place of work of each interviewee and carried out by the researcher herself, in the PHC units of each ESFt. They were conducted in private rooms, with as little external influence as possible, and recorded using digital media, lasting for a mean of 30 minutes. Data collection took place from July to August 2016, and the professionals were approached twice. In the second occasion, they were presented with the transcription of their narratives, so they could change and validate them.

The data collection instrument was a semistructured script, made up by two moments, each including: the sociodemographic and professional profile of the interviewees; and the description of educational practices for the empowering of the families. The latter contained the following triggering questions: How do you carry out the teaching-learning process in your health education practices in the ESF? For you, how should the relation between educator and learner (professional and patient) be in the process of health education? What educational activities do you carry out regarding accidents involving children?

The data to characterize the professionals were compiled in an electronic spreadsheet in the software Microsoft Office Excel 10.0 and went through descriptive analysis. The answers to the triggering questions were transcribed in full, being typed into a text document in the software Microsoft Office Word 10.0.

\section{Data analysis}

The narratives were analyzed using the content analysis technique, thematic modality, following the stages: Pre-analysis, Exploration of material, and Treatment of results/inference/interpretation ${ }^{(17)}$.

The answers were codified and analyzed in a critical-reflective process $^{(9-10)}$, regarding the educational practices developed and problematized through the concepts of dialogism and autonomy that stem from the sociocultural approach of the Brazilian educator Paulo Freire ${ }^{(9)}$. Directives were established for the discussion of the findings, based on the theoretical referents and on principals that should guide educational practices as expressions of care in public health ${ }^{(9,18)}$, divided in evaluative criteria and parameters of the approach, as presented in Figure 1.

After the data collected were codified, they were organized, and the narratives in the interviews were discussed in three thematic categories: Strengths and weaknesses for the dialogic relation in the practice of health education; Developing the teaching-learning process in the professional practice for the empowering and autonomy of the family; and Identifying educational activities in the context of preventing child intoxication. The narratives of professionals were identified using codes with the initial letters of the professional categories in Portuguese, followed by numbers referring to the transcription of the interviews: "Enf1", "Aux1", "ACS1".

\begin{tabular}{|l|l}
\hline \multicolumn{1}{|c}{ Criteria } & \multicolumn{1}{c}{ Parameters } \\
\hline Dialogic relation & \begin{tabular}{l} 
1. Emphasis on critical dialog and on activities \\
that involve the practice of reflection, listening \\
to the other; \\
2. The use of the situations experienced by \\
groups, in the form of dialog; \\
3. A horizontal participation of professionals \\
and family; \\
4. Active subject participation. \\
\hline Health education \\
practices \\
Empowering \\
1. Valuing the knowledge of family, believing \\
that their knowledge is based on their \\
concrete conditions of existence; \\
2. Interactions that establish bonds and \\
respect to particularities; \\
3. Emphasis in the experience and the \\
building of a knowledge between the \\
technical and the popular; \\
autonomy in the family \\
through relations between social subjects.
\end{tabular} \\
\hline
\end{tabular}

Figure 1 - Criteria and parameters for the approach of the practices, Maringá, Paraná, Brazil, July-August, 2016

\section{RESULTS}

Regarding the characterization of the professionals who were interviewed, 46 were female, and the age group varied from 19 to 67 years old, most participants being from 30 to 49 years old. Educational level: most CHAs had complete high school; $42.9 \%$ of nursing auxiliaries had complete higher education; and $77.8 \%$ of the licensed nurses had lato sensu post-graduation courses (Table 1).

Table 1 - Socioeconomic characteristics of professionals interviewed, Maringá, Paraná, Brazil, July-August, 2016

\begin{tabular}{lc}
\hline Variables & Results \\
\hline Female (\%) & 92.0 \\
Age (years), mean & 42.6 \\
Nursing qualification, lato sensu specialization (\%) & 77.8 \\
$\begin{array}{l}\text { Nursing auxiliary educational level, complete higher } \\
\text { education (\%) }\end{array}$ & 42.9 \\
$\begin{array}{l}\text { Community health agent educational level, complete } \\
\text { high school (\%) }\end{array}$ & 70.6 \\
\hline
\end{tabular}

Although the mean professional experience was 10.5 years old in the field of health and 9.2 years old in family health teams, only 13 (26\%) professionals stated to have participated in training sessions to start working in the ESFt. However, all of them stated to have participated in continued education courses every four months, as they exercise their activities. Only $16 \%$ received training for activities to prevent intoxication. 


\section{Strengths and weaknesses for the dialogic relation in the practice of health education}

This category shows the strengths and weaknesses of the dialogic relation in the practice of health education. As the professionals responded to questions about how the relations between educator and learner (professional and patient) should be, according to the parameter of situations experienced by the families, they valued the knowledge of the family through the exchange of experiences and, especially, through dialog. Also, the professionals are inserted in the territory and have a bond with their families, which was seen as a facilitating factor for a dialogic relation.

[...] on the same footing as them, not letting them be ashamed of their questions even when they're pointless. To exchange experiences, sometimes. First, he tells me what he needs and what is happening, and then, we give them some guidance. (Enf3)

First and foremost, to respect the people and listen, because our priority, of us community agents, is to listen to ideas, ways of thinking, respecting their beliefs and advancing conversations based on these premises. (ACS28)

By exchanging experiences, because patients know very well and have a lot to teach too. So we always sit in a circle and talk. It's not like we're on foot and they are siting, everyone is sitting down and on the same level. (Aux7)

The horizontal nature of this educational practice was not manifested in the statements of all professionals, but was narrated by professionals from all categories.

I think that we must be equal, act as if it wasn't from top to bottom, but between equals [...] starting from their reality so they can clarify any doubts. I explain, some subject is raised, we talk, this is nice. (Enf2)

Clear language, a language they can understand. Sometimes you talk, and they pretend they understood, but they didn't understand anything. So you try a clearer and more popular language, so they can understand and don't get frightened. (Aux6)

It was possible to infer that the use of scientific terms by professionals is seen as a barrier for the dialog with the families. Therefore, they seek to use a clearer language that is more accessible by the population.

Sometimes, we see the physician speaking with a little more theory, and the patients don't understand. We come back later, and they say they don't understand. Sometimes, they don't tell the physician, they get embarrassed, but to us, the CHAs, they say it. (ACS14)

The exchange of knowledge must be as natural as possible, transmit it as accessibly as possible to the population, because the patient frequently can't understand the technical terms, scientific terms, in a conversation and they don't know what to do for their treatment, for instance. (Enf6)

Although the statements indicate a valuing of the knowledge for the process of health education, most professionals did not mention the active participation of the subjects in the teaching-learning process, and, therefore, show their rigidity in the education process.

This process of teaching the patient is very difficult, because they just learn and listen to what they want; if it isn't connected to their consultation, they won't come. (Enf4)

That story of promotion and prevention is still very distant from the community. They only believe in medical treatments. (ACS4)

There are patients who, sometimes, don't follow treatment or something like that, so you have to be stern with them. I'm more the type to blackmail them, to get them afraid. (Aux7)

In these circumstances, it should be highlighted that valuing the knowledge of the families in the context of their territory, creating bonds, and having dialog are strengths of the dialogic process in the practice of health education. However, the lack of involvement of families in this process is seen as a weakness in the dialogic relation, transforming the educational practice of the professionals in a top-to-bottom affair.

\section{Developing the teaching-learning process in the profes- sional practices for the empowering and autonomy of the family}

When the CHAs were asked about how they develop their teaching-learning process to empower and promote the autonomy of the family in the context of the ESFt, it was found that they consider, especially, knowledge, experiences, and the valorization of popular knowledge. The interactions in which bonds of confidence are established and the respect to particularities were also mentioned by many professionals.

[...] we end up giving recommendations, always considering the reality of the person we're advising, because it's pointless for me to say "you must buy this" if the person can't afford it. (ACS12)

[...] if I treat a patient aggressively and I want to impose myself, it won't work, it will break the bond I was trying to keep. (ACS6)

First I need to have a bond with the patient so he can trust me. The rest flows from this bond. It has to be like a relation of real trust. (ACS30)

Mutual bonds and respect. I think that I have to gain the trust of this patient. He needs to trust me as a professional, to trust me as a person. (Enf9)

There are some patients we adopted around here. You create such a strong bond [...] we even have the number of their relatives. (Aux3)

However, some practices mentioned by the professionals during the teaching-learning process did not establish the construction of knowledge between the technical and popular knowledge and were punitive towards the families.

I have to scare some of them into adhering. I don't know if it's right, but it's what I do, by explaining the risks "if you don't do 
this, that will happen", in the clearest, most direct and upfront way possible. (Enf2)

So we kind of go to their weakest spot: their fear of dying. (ACS7)

I'll give you an example. Sometimes we even make up examples we don't have, just to make the person afraid so they won't do it. (ACS4)

Some professionals stated not to promote the strengthening of individuals and/or groups through the relations between social subjects. However, these professionals seem to be in a transition stage of their educational practices, as shown in some statements, especially by nurses.

We've entered the houses of these people and we know how they're inside. We do our part, which is giving advice. If they'll follow it, if they'll do it, that's their problem. (ACS9)

We're working and trying to change this point of view focused on curing and aiming towards promotion and prevention; actually, especially towards health promotion. (Enf1)

We work by building a work plan and demystifying everything that is going on in the community. The community is where the health education process takes place, and we carry out our activities according to the openings it shows for the educational process, because you can't stop the work dynamic, it's a continuous process of learning. (Enf8)

Considering this setting, it stands out that the interaction of the ESFt for promoting family autonomy is developed through bonds of trust, respect, and valorization of the community knowledge. However, it is still necessary to rethink the domain of technical knowledge, and to reconsider the strengthening of the relations that exist between social subjects and the communication between them, including their opening and availability for dialogic relations, without any punishment for the families.

\section{Identifying educational activities in the context of prevent- ing child intoxication}

This category represents the conditions that cause the phenomenon under study. When asked about the activities they develop regarding child intoxication, most professionals responded that they develop "no activity" or few activities, but they believe the families could be trained to prevent intoxications in their homes.

I'll only give advice if I see something, but no, I don't address something specific. (ACS34)

It has to be addressed in their homes, in the home visits [...], in their home, we see what is happening, how things are. Sometimes it's not even the mother who takes care of the child. Sometimes it's the grandmother, so I think this has to be at their home. (Enf1)

Ithink the easiest way is the home visit, really, because to convince them to get out of their homes and come participate is very hard. (ACS25)

In addition to the space of their homes, many narrated that other environments that favor social interaction, such as schools and nursing homes, can be used as spaces to train the families in the prevention of intoxications and safety at home.

I think the schools and nursing homes should organize for the teachers to call families, or we should organize this with the schools. This would be a very good way, because the approach would address bot the kids and their parents. (Enf8)

If you do this at the school, the public will be greater and both mother and father will be present, or grandmother and grandfather, and even an older brother who brings the kid home. (ACS12)

Paradoxically, the workers mentioned the families themselves as a barrier for the education activities to promote health and prevent child intoxication.

Normally, the population comes here to the unit and wants a cure, they don't care much about preventing, about a healthy life. (Enf7)

It's really hard for them to participate, because they don't adhere to this type of thing; unless they get some benefit, they gain something, otherwise no one really shows interest. (ACS25)

Prevention, for them, doesn't exist, they always just want the medication [...] it would be much more interesting if it was really just family health. (ACS32)

The professionals show that, although families have the potential to prevent child intoxications, they sometimes limit it when they avoid active participation and do not become involved in education activities, seeking only a type of assistance based on the biomedical model.

\section{DISCUSSION}

The sociodemographic characteristics of the professionals interviewed influence the variables of the teaching-learning process in the context of child intoxication, considering the references used for this study ${ }^{(9)}$, since they integrate a team of professionals inserted in the community, who have established a bond with it throughout the years. To this end, it was found that these characteristics corroborate data on the composition of the Brazilian health workforce: most are female, young, with a higher educational level than required for their work, not to mention a high number of professionals with lato sensu postgraduation courses ${ }^{(3,19)}$.

It was necessary to organize the understanding of educational practices developed and problematized by the concepts of dialogism and autonomy, as divided in evaluative criteria and parameters ${ }^{(9)}$ (practices in health education and promotion of family autonomy), to comprehend the multiple factors that affected and determined the relations of empowerment and dialog of the families, required for child intoxications could be dealt with.

Regarding the conceptual framework for the dialogic relations in the practice of health education, which was presented in the first thematic category, the participants and the users share, according to some statements, their knowledge. This is done through active listening, dialog, the exchange of experiences, through teaching and learning, and showing the change in perspective that avoids a 
reductionist view of the health-disease binomial. Health education, carried out according to Paulo Freire's guidance, makes it possible to strengthen the bonds and the trust between health services and users with regard to spaces of dialog and construction of knowledge and practices. In these practices, users and professionals discuss strategies to confront their problems in group, to propose alternatives and realize effective health practices that can be integral and capable of solving the problems $s^{(5,20-21)}$. It stands out that the knowledge and practices must be understood by the health professionals and respected, valued, and treated horizontally. When one considers the words and the knowledge of their users, there is a higher chance of educating, of improving behavior. One must respect and consider the culture of people and promote the empowering of the action and reflection, so there is a change in behavior ${ }^{(9,20-21)}$.

However, narratives were weak with regard to a dialogic relationship with the families in practice and the use of methodologies to empower and give autonomy to them. This could be observed in the statements about the fact that subjects did not participate in the process, and in those about the authoritarianism of the professionals. It can be understood, as a result, that the educational practices that are dialogic and, consequently, emancipatory, can be less frequent among the professionals due to their own personal experiences and professional formation, which can be distant from reality ${ }^{(22)}$.

Regarding the process of dialogic relations with the families, the fact that some professionals live in the territory of the ESFt was pointed out as an instrument that facilitates the establishment of bonds. When the workers take action regarding health promotion and the prevention of child intoxications, they use different technologies, and belonging to the same community as the family who is being cared for is an element that connects them, a "link" between the population and of the territory and the team as a whole ${ }^{(23)}$.

Considering the active listening and critical dialog parameters, the horizontality of professional and family, and the active participation of people and groups in the teaching-learning process, the group interviewed presented multiple and occasionally contradictory narratives, with regard to how they believed the relation between educator and learner should take place. The use of devices from the traditional model of education in health repeated itself in the narratives, especially as the workers were rigid in the process of educating the families and did not bring them into this process active members of it. Bringing into effect educational practices that are actually committed to the emancipation of the subjects is a challenge that must be faced in the process of work of the interviewees, since this type of education is still rare. Traditional methodologies which compromise the creation of a bond between the professionals and the population continue to be used, especially with regard to blaming the family for toxicological events ${ }^{(21-22)}$.

Regarding the use of methodologies to guide the teachinglearning process that empowers and promotes the autonomy of the families within ESF practice, there has been a theoretical transition of educational practices, as the second thematic category shows. The change is from a reductive perspective about the health-disease binomial into a perspective that involves the exchange of knowledge as the main condition for a transformative education ${ }^{(24)}$. Considering how the knowledge and experiences of the family are valued, the integration between technical knowledge, popular knowledge, and personal and/or group improvement through the relations of trust between professionals and family, the interviewees were seen to understand Paulo Freire's presuppositions ${ }^{(9)}$, but do not seem to use them in practice. There is an observable trend towards the effective employment of the dialogic model, but the community, as well as the workers in the field of health, must change the predominant point of view according to which health is the absence of disease, also changing actions based on the transmission of information that relies on emphasizing the possibility of becoming ill (21-22).

In the same vein, the activities developed by the workers in this study are, still, focused on disease and on the use of traditional methodologies, such as educational practices focused on the prevention of diseases and health problems. Although activities focused on the prevention of diseases and health problems are important, considering the epidemiological changes in health, educational practices targeted at health promotion, which include the family, express the opportunity of providing an integral care to health, considering the complexity and interaction between users, families, professionals, and society ${ }^{(25)}$. These educational practices are directed at the transformation of the behavior of people, so they can act in the improvement of their quality of life and health. This includes a stronger participation in society, so they can have control over this process ${ }^{(26)}$.

Professionals mentioned little involvement in activities to prevent child intoxication and were unaware of the reality of the families concerning intoxication, as the third thematic category showed. Considering these premises, child intoxication has been discussed as an event where the values and beliefs of a family are important causal factors - the existence of toxic plants around the houses to "protect the family", the use of highly toxic cleaning products to diminish the personal effort spent in cleaning, the self-medication and storage of drugs at home ${ }^{(4,27)}$.

The educational practices for this event should be based on an approach that not only demands more attention from adult caregivers when children are at risk of accidents, but also discusses the socioenvironmental determinants and the vulnerability of the families ${ }^{(28)}$. Considering Paulo Freire's presuppositions, they should include the "3 Es" - Education, Engineering, and Enforcement, to which Economy and Environment can be added ${ }^{(29)}$.

The professionals interviewed considered that families can be addressed to prevent intoxication in their houses, that is, according to their social reality, and recognize other spaces, in addition to the home spaces, to interact with them in the prevention of intoxication. If these activities are only articulated as norms, they become general conducts and procedures to solve health problems, but do not guarantee a type of care that can respond to the needs of children and to the ways of life of their families. If an educational practice is to be, simultaneously, a care practice, with the power to transform health, it must be reasonable, participative, non-coercive or punitive, and focused on the family, as opposed to revolving around aspects of its inability to promote safety measures in the home environment ${ }^{(9,28)}$.

To develop educational activities in the context of child intoxication, the social, economic, and cultural contexts of the individuals involved in the educational process must be considered ${ }^{(30)}$. One must seek a humane practice, that privileges health promotion 
against the curative model, emphasizing the principles of integral and equal health, based on the presuppositions of Paulo Freire (dialog, participation, and autonomy) as a possible way to reorganize education and care-related practices of health ${ }^{(9)}$.

In this context, the narratives that mentioned the families themselves as barriers for educational activities were opposed to the discourse for the transition of educational practices in general. In other words, there is a theoretical and general approximation to the perspective of Paulo Freire, while the distance from them is greater in the specificities of daily practice. Educational interventions should be constructed in society (family, school, health units, churches) in a participative and co-responsible manner, with multisectoral and universal interventions. The communities and the participation of the community must be the goal, involving environmental changes, as well as the implantation of public policies and legislation ${ }^{(27,29)}$.

\section{Study limitations}

The context in which the research was carried out can be seen as its limitation, since this is a study involving the ESFts of a city with its own specific characteristics, although the interviewees shared professional and social characteristics that are true for the whole country. For many reasons, the professionals presented care for child intoxication as something dispensable, which is not their responsibility.

\section{Contributions to the fields of Nursing, Health or Public Policy}

The dialogic action, as a strategy to empower the families, stands out as a contribution of this research for the professional practice of nursing, as it targets the attention of the health needs and is based on a teaching-learning process which includes strategies that allow for the active participation of subjects capable of forming competent ESFts professionals, with the necessary skills to generate changes in the practices of education in health to deal with child intoxication.

\section{FINAL CONSIDERATIONS}

The strategies used in the educational practices to prevent against child intoxication were focused on traditional health models of education, without the active participation of the families, although professionals stated that they carried out collective practices, targeted at increasing the autonomy and wellbeing of the same families. This suggests that they are in a transition stage between the curative/biomedical model and the dialogic one.

Dialogic educational practices about child intoxication, which is a complex and multifaceted phenomenon, must recognize homes and social spaces as priorities for their practice. However, the discourse that blames the families for intoxications must be pushed away from the educational process, and dialog must be more frequent for the promotion of health and the prevention of intoxication, in a way that targets the social reality of these families.

\section{FUNDING}

This work was carried out with the support of the Coordination for the Improvement of Higher Education Personnel - Brazil (CAPES) - Financing Code 001, from March/2015 to February/2017.

\section{REFERENCES}

1. Wynn PM, Zou K, Young B, Majsak-Newman G, Hawkins A, Kay B, et al. Prevention of childhood poisoning in the home: overview of systematic reviews and a systematic review of primary studies. Int J Inj Contr Saf Promot. 2016;23:3-28. https://doi.org/10.1080/17457300.2015.1032978

2. Disfani HF, Kamandi M, Mousavi SM, Sadrzadeh SM, Farzaneh R, Doolabi N, Rahmani K. Risk factors contributing to the incidence and mortality of acute childhood poisoning in emergency department patients in Iran: a hospital-based case-control study. Epidemiol Health. 2019;41:e2019016. https://doi.org/10.4178/epih.e2019016

3. Sales CCFS, Oliveira MLF. Health education practices of poisoning prevention for child in Family Health Strategy. Esc Anna Nery. 2019;23(1):e20180140. https://doi.org/10.1590/2177-9465-EAN-2018-0140

4. Vilaça L, Volpe FM, Ladeira RM. Accidental poisoning in children and adolescents admitted to a referral toxicology department of a Brazilian emergency hospital. Rev Paul Pediatr. 2020;38:e2018096. https://doi.org/10.1590/1984-0462/2020/38/2018096

5. Brandão Neto W, Silva MAI, Aquino JM, Lima LS, Monteiro EMLM. Violence in the eye of adolescents: education intervention with Culture Circles. Rev Bras Enferm. 2015;68(4):617-25. https://doi.org/10.1590/0034-7167.2015680407i

6. Roma KMS, Gomes MFP, Reticena K, Capellini VK, Fracolli LA. Prevenção de acidentes na primeira infância na estratégia saúde da família: perspectiva dos pais. Rev Enferm UFPI [Internet]. 2018 [cited 2020 Oct 23];7(2):28-34. Available from: https://revistas.ufpi.br/index.php/ reufpi/article/view/6670/pdf

7. Amestoy SC, Oliveira AFL, Thofehrn MB, Trindade LL, Santos BP, Bao ACP. Contributions of Paulo Freire to understanding the dialogic leadership exercise of nurses in the hospital setting. Rev Gaúcha Enferm. 2017;38(1):e64764. https://doi.org/10.1590/1983- 1447.2017.01.64764

8. Lee BS, Eo YS, Lee MA. Leadership experience of clinical nurses: applying focus group interviews. J Korean Acad Nurs. 2015;45(5):671-83. https://doi.org/10.4040/jkan.2015.45.5.671

9. Freire P. Pedagogia da autonomia: saberes necessários à prática educativa. 53. ed. São Paulo: Paz e Terra; 2016.

10. Labegalini CMG, Nogueira IS, Hammerschmidt KSA, Jaques AE, Carreira L, Baldissera VDA. Educational and care-related dialogical pathway on active aging with family health strategy professionals. Texto Contexto Enferm. 2020;29:e20180235. https://doi. org/10.1590/1980-265X-TCE2-2018-0235 
11. Rodrigues DMMR, Nogueira IS, Higarashi IH, Heidemann ITSB, Baldissera VDA. Critical disclosures about sexuality among elderly women as a dialogical educational assessment device. Rev Baiana Enferm. 2019;33:e27754. https://doi.org/10.18471/rbe.v33.27754

12. Dignam D, Duffield C, Stasa H, Gray J, Jackson D, Daly J. Management and leadership in nursing: an Australian educational perspective. J Nurs Manag. 2012;20(1):65-71. https://doi.org/10.1111/j.1365-2834.2011.01340.x

13. Gil AC. Como elaborar projetos de pesquisa.6a ed. São Paulo: Atlas; 2017.

14. Tong A, Sainsbury P, Craig J. Consolidated criteria for reporting qualitative research (COREQ): a 32-item checklist for interviews and focus groups. Int J Qual Health Care. 2007;19(6):349-57. https://doi.org/10.1093/intqhc/mzm042

15. Ramos CFV, Silva MSB, Rosa AS, Santana CLA, Tanaka LH. Educational actions: an action research with Family Health Strategy professionals and users. Rev Bras Enferm. 2020;73(5):e20180969. https://doi.org/10.1590/0034-7167-2018-0969

16. Castellanos METP. The narrative in qualitative research in health. Ciênc Saúde Colet. 2014;19(4):1065-76. https://doi. org/10.1590/1413-81232014194.12052013

17. Minayo MCS. O desafio do conhecimento: pesquisa qualitativa em saúde. 14a ed. São Paulo: Editora Hucitec; 2015.

18. Ministério da Saúde (BR). Secretaria de Vigilância em Saúde. Secretaria de Atenção à Saúde. Política Nacional de Promoção da Saúde. Brasília (DF): Ministério da Saúde; 2015.

19. Machado MH, Aguiar Filho W, Lacerda WF, Oliveira E, Lemos W, Wermelinger M, et al. Características gerais da enfermagem: o perfil sócio demográfico. Enfermagem em foco [Internet]. 2016 [cited 2020 Oct 23];3(Esp):9-14. Available from: http://revista.portalcofen.gov.br/index. php/enfermagem/article/view/686/296

20. Rodrigues DMMR, Labegalini CMG, Higarashi IH, Heidemann ITSB, Baldissera VDA. The dialogic educational pathway as a strategy of care with elderly women in sexuality. Esc Anna Nery 2018;22(3):e20170388. https://doi.org/10.1590/2177-9465-EAN-2017-0388

21. Soares NA, Souza V, Santos FBO, Carneiro ACL, Gazzinelli MF. Dispositivo educação em saúde: reflexões sobre práticas educativas na Atenção Primária e formação em enfermagem. Texto Contexto Enferm. 2017;26(3):e0260016. https://doi.org/10.1590/0104-07072017000260016

22. Porto LA, Valente RN, Esteves CO, Escalda J. Práticas de aleitamento materno: concepções das trabalhadoras de saúde de um hospital público de Salvador. Rev Baiana Saúde Pública [Internet]. 2018 [cited 2020 Oct 23];42(4):653-70. Available from: http://www.rbsp.sesab. ba.gov.br/index.php/rbsp/article/view/2828/2568

23. Assis AS, Castro-Silva CR. Agente comunitário de saúde e o idoso: visita domiciliar e práticas de cuidado. Physis: Rev Saúde Coletiva [Internet]. 2018 [cited 2020 Oct 23];28(3):e280308. Available from: https://www.scielosp.org/pdf/physis/2018.v28n3/e280308/pt

24. Viaro VD, Linhares FMP, Coriolano-Marinus MWL, Guedes TG, Vanderley LSL. Limits and possibilities for teaching and learning about breastfeeding. Rev Bras Enferm. 2019;72(1):3-8. https://doi.org/10.1590/0034-7167-2018-0017

25. Fagundes DQ, Oliveira AE. Educação em saúde no pré-natal a partir do referencial teórico de Paulo Freire. Trab Educ Saúde. 2017;15(1):22343. https://doi.org/10.1590/1981-7746-sol00047

26. Santos FPA, Acioli S, Rodrigues VP, Machado JC, Souza MS, Couto TA. Nurse care practices in the Family Health Strategy. Rev Bras Enferm. 2016;69(6):1060-7. https://doi.org/10.1590/0034-7167-2016-0273

27. Uthkarsh PS, Suryanarayana SP, Gautham MS, Shivraj NS, Murthy NS, Pruthvish S. Profile of injury cases admitted to a tertiary level hospital in south India. Int J Inj Contr Saf Promot. 2012;19(1):47-51. https://doi.org/10.1080/17457300.2011.603149

28. Nascimento EN, Gimeniz-Paschoal SR, Sebastião LT. Prevention of domestic child accidents: an educational intervention conducted by Speech Therapy trainees in a Family Health Care Unit. Rev CEFAC. 2019;21(5):e17018. https://doi.org/10.1590/1982-0216/201921517018

29. Patel D, Sandell JM. Prevention of unintentional injury in children. Paediatrics Child Health. 2013;23(9):402-8. https://doi.org/10.1016/j. paed.2013.06.001

30. Branquinho ID, Lanza FM. Child health in primary care: evolution of brazilian policies and nurses' performance. Rev Enferm C-Oeste Min. 2018;8:e2753. https://doi.org/10.19175/recom.v8i0.2753 